\title{
PENGEMBANGAN MEDIA PEMBELAJARAN K3 BERBASIS ANDROID SEBAGAI STRATEGI EDUKATIF UNTUK MELATIH SISWA SMK SEBAGAI TENAGA KERJA TERAMPIL DI PASAR GLOBAL
}

\author{
Yusron Mubarok \\ SMK Negeri 1 Bukateja, Purbalingga \\ E-mail: yusronmubarok@gmail.com
}

\begin{abstract}
ABSTRAK
Tujuan dari penelitian ini adalah untuk mengidentifikasi kebutuhan, mengembangan, dan mengetahui kelayakan media pembelajaran berbasis android pada mata diklat K3. Penelitian ini merupakan penelitian pengembangan dengan memodifikasi model Sugiyono yang dilakukan di Program Keahlian Teknik Kendaraan Ringan Otomotif SMKN 1 Bukateja Purbalingga. Hasil identifikasi didapatkan (a) Jenis teks "Times New Roman", (b) Ukuran teks "15 pt", (c) Warna teks "Mengikuti Background", (d) Tata letak teks "Rata Kanan Kiri", (e) Letak gambar pendukung "Pada Bagian Awal", (f) Warna background "Kebiruan", (g) Keterangan tombol "Berbentuk Teks", (h) Jenis animasi tombol "Animasi Gerak", (i) Backsound "Off", (j) Efek suara tombol "Klik. Pengembangan media pembelajaran terdiri dari (a) desain produk, (b) pengumpulan bahan produk, (c) pembuatan produk (d) penilaian produk, (e) revisi produk I, (f) Uji coba produk, (g) revisi produk II. Kelayakan media pembelajaran dikategorikan "sangat layak", sehingga media pembelajaran ini dapat digunakan sebagai pelengkap proses belajar mengajar.
\end{abstract}

Kata kunci: Android, K3, Media Pembelajaran

\section{DEVELOPING ANDROID BASED K3 LEARNING MEDIA AS AN EDUCATIVE STRATEGY TO TRAIN STUDENT OF VOCATIONAL SCHOOL TO BE PROFESSIONAL WORKER IN THE WORLD-GLOBAL MARKET}

\begin{abstract}
This research aimed to (1) identify the type of android-based learning media suitable for the vocational school's students, (2) develop android-based learning media, and (3) validate the android-based learning media. This study is a Research and Development $(R \& D)$ adapted from Sugiyono's Model. It took place in a Public Vocational High School in Purbalingga. Research data were collected using questioner dan analysed using descriptive analysis. The result showed that: (1) the identifed of learning media necessary were (a) font "Times New Roman", (b) font size "15 pt", (c) font colour "following Background", (d) align text "justify", (e) picture orientation "above", (f) background colour "blue", (g) button tittle "text", (h) button animation "moving", (i) backsound "Off", (j) button sound effect "Click". There were seven steps of (2) developing learing media, they are (a) designing product, (b) Collecting product's source, (c) creating product, (d) validating product, (e)
\end{abstract}


revising $I$, (f) testing product, ( $g$ ) revising II. The (3) learning media was categorized "very good" meant that this media learning was valid to used.

Keywords: Android, K3, Learning Media

\section{PENDAHULUAN}

Pendidikan merupakan suatu proses pembelajaran untuk mengembangkan potensi, kecakapan dan karakteristik pribadi peserta didik melalui usaha sadar dan terencana. Potensi, kecakapan, dan karakter ini merupakan modal utama untuk meningkatkan daya saing Sumber Daya Manusia (SDM) pada suatu bangsa.

Pendidikan di Indonesia terdiri dari tiga tingkatan yaitu pendidikan dasar, pendidikan menengah (Dikmen), dan pendidikan tinggi. Dikmen sendiri terdiri dari sekolah menengah umum dan kejuruan. Salah satu Sekolah Menengah Kejuruan (SMK) yang ada di Jawa Tengah adalah SMK Negeri 1 Bukateja, Pubalingga. Sekolah ini bertujuan untuk menyiapkan lulusannya agar menjadi SDM yang siap bersaing di dunia kerja. Selain itu, untuk mendukung tercapainya proses pembelajaran yang berkualitas SMK Negeri 1 Bukateja, meningkatkan sarana dan prasarana pendukung. Salah satu diantaranya dengan terus berusaha menyediakan media pembelajaran inovatif yang dibutuhkan dalam PBM. Media pembelajaran membantu siswa menyiapkan dan menerima mata diklat karena siswa dapat belajar terlebih dahulu di rumah.

Di tengah pendidikan yang terus ditingkatkan, Indonesia juga terus meningkatkan kesiapan menghadapi tantangan global. Asean Economic Community (AEC) atau yang dalam bahasa Indonesia disebut dengan Masyarakat Ekonomi Asean (MEA) merupakan hasil kesepakan negara Asia Tengggara untuk membuat sebuah pasar raksasa yang memungkinkan terjadinya perdagangan antar anggotanya dengan mudah. Salah satu bentuk kebijakannya dengan membebaskan bea masuk (Free Trade Area). Basis produksi yang digalakan ini menjadikan arus barang, jasa, investasi dan tenaga terampilserta aliran modal pun lebih mudah dan bebas keluar masuk ke suatu negara (Ditjenkpi.kemendag, 2014) Kesepakatan itu terbentuk dalam KTT Association of Southeast Asian Nation (ASEAN) ke-9 yang diselenggarakan di Provinsi Bali tahun 2003, antar seluruh kepala negara anggota ASEAN telah menyepakati pembentukan komunitas ASEAN dengan dideklarasikannya Bali concord II dalam KTT ASEAN tersebut. Itulah awal dimana kita kemengenal istilah MEA.

MEA membuka kesempatan kerja seluas-luasnya bagi warga negara ASEAN. Setiap warga negara dapat keluar masuk dari satu negara ke negara lain untuk mendapatkan 
pekerjaan yang diinginkan tanpa adanya hambatan dari negara yang ditujunya itu (Ditjenkpi.kemendag, 2014). Indonesia sebagai salah satu negara yang menyepakati MEA juga memiliki kesempatan yang sama. Untuk itu, kita harus mempersiapkan segala sesuatunya. Salah satu hal yang perlu disiapkan tentunya tenaga kerja yang terampil (skilled labor)

Skilled labour merupakan pekerja yang mempunyai keterampilan atau keahlian khusus, pengetahuan, dan keterampilan baik lulusan perguruan tinggi, akademisi, sekolah teknik ataupun pengalaman kerja. (Ditjenkpi.kemendag, 2014). Dalam industri modern dewasa ini yang rumit dan pelik penyelenggaraannya, kecelakaan dalam perusahaan dan penghindarannya tidak dapat diabaikan begitu saja. Program penghindaran kecelakaan dapat berbeda menurut jenisnya; misalnya pada suatu tempat kerja tertentu harus ada alat pelindung pada mesin dan instrumen, sedangkan ditempat lain harus ada penerangan, ventilasi. (Djoko; 2005). Peran dunia pendidikan Indonesia menjadi penting untuk menyiapkan para tenaga kerja. Dalam hal ini penulis memfokuskan pada penerapan Kehatan dan Keselamatan Kerja (K3).

Disisi lain dalam perkembangan teknologi informasi terjadi fenomena yang menarik, yaitu perkembangan penggunaan gadget. Menurut data yang tercatat di Kementerian Komunikasi dan Informatika, angka masyarakat pengguna gadget di Indonesia menyentuh 240 juta unit. Hal tersebut cukup mengejutkan mengingat jumlah penduduk Indonesia yang saat ini berada di kisaran angka 230 juta jiwa (Dwi; 2013). Data dari opera, perusahaan yang berperan sebagai web browser menyebutkan bahwa pengguna gadget dengan OS android yang berumur 13 sampai 24 tahun mencapai angka 44\% (Bambang; 2013). Dari data tersebut menunjukan bhawa hampir setengah dari pengguna gadget di Indonesia merupakan pengguna yang berada diusia sekolah menengah (SMP-SMA sederajat) dan mahasiswa.

Perkembangan teknologi gadget dikalangan siswa tersebut memberi peluang yang bisa dimanfaatkan oleh dunia pendidikan, salah satunya lewat pengembangan media pembelajaran berbasis Android. Pengembangan media pembelajaran ini memungkinkan siswa untuk dapat belajar mandiri, sehingga nilai kemandirian dalam pendidikan karakter dapat diterapkan dalam kehidupan sehari-hari. Oleh karena itu, peneilitian ini bertujuan untuk mengidentifikasi kebutuhan, mengembangan, dan mengetahui kelayakan media pembelajaran berbasis Android. 


\section{METODE PENELITIAN}

Metode penelitian yang digunakan dalam penelitian ini adalah metode penelitian dan pengembangan atau dikenal dengan Research and Development. Penelitian pengembangan menurut Endang Mulyatiningsih (2011: 145) merupakan penelitian yang bertujuan menghasilkan produk baru melalui proses pengembangan. Menurut Richey dan Klein dalam Emzir (2010: 264) menyatakan bahwa penelitian pengembangan merupakan salah satu jenis penelitian pragmatik yang menawarkan suatu cara untuk menguji teori dan memvalidasi praktik yang terus menerus dilakukan secara esensial. Suatu cara menetapkan prosedurprosedur, teknik-teknik, dan peralatan-peralatan baru yang didasarkan pada suatu analisis metodik tentang kasus-kasus spesifik.

Menurut Triyanto (2010: 206) penelitian pengembangan adalah serangkaian proses dalam rangka mengembangkan suatu produk baru atau menyempurnakan produk yang sudah ada agar dapat dipertanggungjawabkan. Produk tersebut dapat berupa perangkat keras atau perangkat lunak. Perangkat keras seperti buku, modul, alat bantu pembelajaran. Perangkat lunak dapat berupa program komputer, model pendidikan, pembelajaran pelatihan atau evaluasi. Menurut Sugiyono (2010: 298) penelitian pengembangan merupakan penelitian yang bertujuan adalah upaya untuk mengembangkan dan menghasilkan suatu produk berupa materi, media, alat, atau strategi pembelajaran, digunakan mengatasi di kelas, dan bukan untuk menguji teori di kelas. Berdasarkan definisi beberapa ahli di atas dapat disimpulkan bahwa penelitian pengembangan merupakan penelitian yang memiliki tujuan untuk mengembangkan dan menghasilkan suatu produk.

Penelitian ini dilakukan pada Januari hingga Maret 2019 di SMK Negeri 1 Bukateja, Purbalingga. Jawa Tengah yang bertujuan untuk mengembangkan media pembelajaran berbasis android dengan materi K3. Kegiatan pengembangan dilakukan dengan memodifikasi model penelitian dan pengembangan Sugiyono yang terdiri dari: (1) analisis kebutuhan, (2) membuat desain, (3) pengumpulan bahan, (4) membuat produk (5) validasi produk, (6) revisi I, (7) Uji coba produk, (8) revisi II atau produk akhir.

Model yang dikembangkan selanjutnya divalidasi oleh ahli materi, media, dan juga siswa selaku pengguna media pembelajaran. Instrumen yang dipergunakan berupa angket/kuesioner. Data yang terkumpul selanjutnya dianalisis secara deskriptif. Penilaian kelayakan media pembelajaran yang dihasilkan mengacu pada Arikunto (2010: 35) yang mengatakan bahwa data kuantitatif yang berwujud angka-angka hasil perhitungan atau pengukuran dapat diproses dengan cara dijumlah, dibandingkan dengan jumlah yang diharapkan dan diperoleh presentase. Rumus yang dipergunakan yaitu sebagai berikut: 


$$
\text { kelayakan }=\frac{\text { Skor yang diobservasi }}{\text { Skor yang diharapkan }} \times 100 \%
$$

Tabel 1. Skala persentase Suharsimi Arikunto

\begin{tabular}{lc}
\hline Persentase pencapaian & Klasifikasi Kelayakan \\
\hline $81-100 \%$ & Sangat Layak \\
$61-80 \%$ & Layak \\
$41-60 \%$ & Cukup Layak \\
$21-41 \%$ & Kurang Layak \\
$0-20 \%$ & Tidak Layak \\
\hline
\end{tabular}

\section{HASIL DAN PEMBAHASAN}

\section{Kebutuhan Media Pembelajaran}

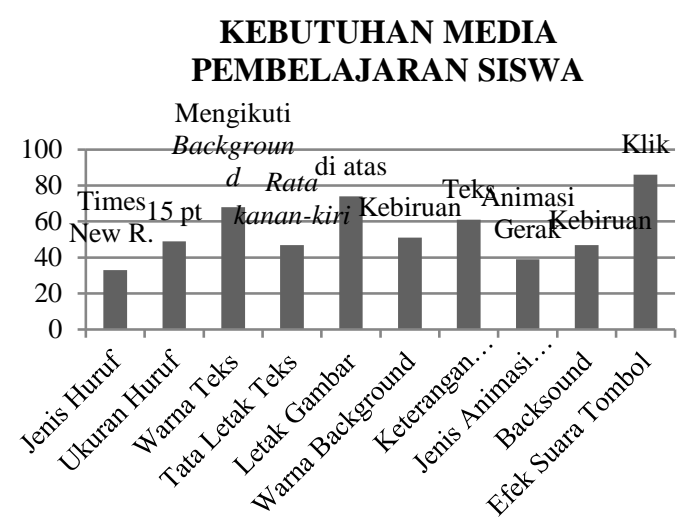

Gambar 1. Kebutuhan media pembelajaran siswa

Analisis tersebut dilakukan pada data atau informasi yang didapat dari hasil penyebaran angket. kelas X TKRO 5 yang berjumlah 36 siswa. Data identifikasi kebutuhan media pembelajaran siswa dapat diamati pada gambar 1 .

\section{Pembuatan Media Pembelajaran}

Pengembangan media pembelajaran bertujuan untuk membuat media yang dapat membantu siswa dalam memahami materi-materi yang disampaikan oleh guru. Berdasarkan identifikasi kebutuhan media pembelajaran siswa dilakukan pembuatan media pembelajaran.

a. Desain Media Pembelajaran

Setelah didapatkan identifikasi kebutuhan kemudian dibuat desain (rancangan) media. Hasil diskusi grup ini berupa rancangan yang ini terdiri dari rancangan fungsi, skenario, storyboard. 
b. Pengumpulan Bahan Media Pembelajaran

Pengumpulan bahan untuk membuat media pembelajaran ini disesuaikan pembelajaran.

Maka dari itu peneliti berkonsultasi dengan guru lain yang juga mengampu pelajaran yang sama.

c. Pembuatan Media Pembelajaran

Langkah berikutnya adalah pembuatan media pembelajaran. Pembuatan media ini didasarkan pada identifikasi kebutuhan dan pengumpulan bahan media pembelajaran.

\section{Data Uji Kelayakan Media}

\section{Penilaian oleh Ahli Materi}

\section{Penilaian oleh Ahli Materi}

Pada penilaian oleh ahli materi terdapat dua aspek penilaian utama yaitu aspek kualitas materi dan aspek kebermanfaatan materi. Uji kelayakan ini dilakukan oleh guru senior yang mengajar materi kelistrikan kelas XII, sedangkan ringkasannya dapat dilihat pada gambar 2.

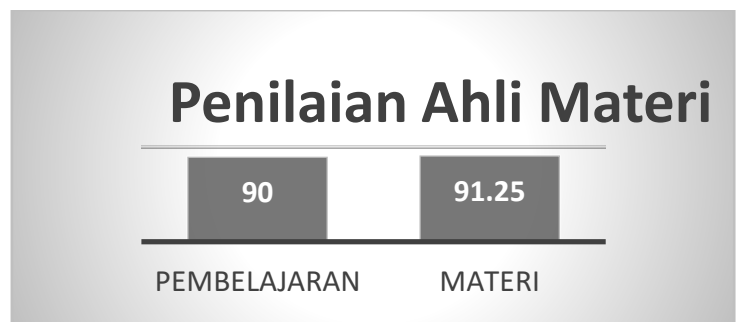

Gambar 2. Hasil penilaian ahli materi

Berdasarkan skor penilaian media pembelajaran oleh ahli materi didapat nilai kelayakan 90,62\% dengan klasifikasi kelayakan "Sangat Layak".

2. Revisi oleh Ahli Materi

Adapun beberapa komentar dari ahli materi tersebut adalah sebagai berikut:

a. Kurang jelasnya penggunaan istilah pada indikator pada KIKD.

b. Pemberian label pada materi sesuai KD agar pengguna lebih mudah mengidentifikasi materi tersebut.

c. Diberi petunjuk waktu pengerjaan soal 

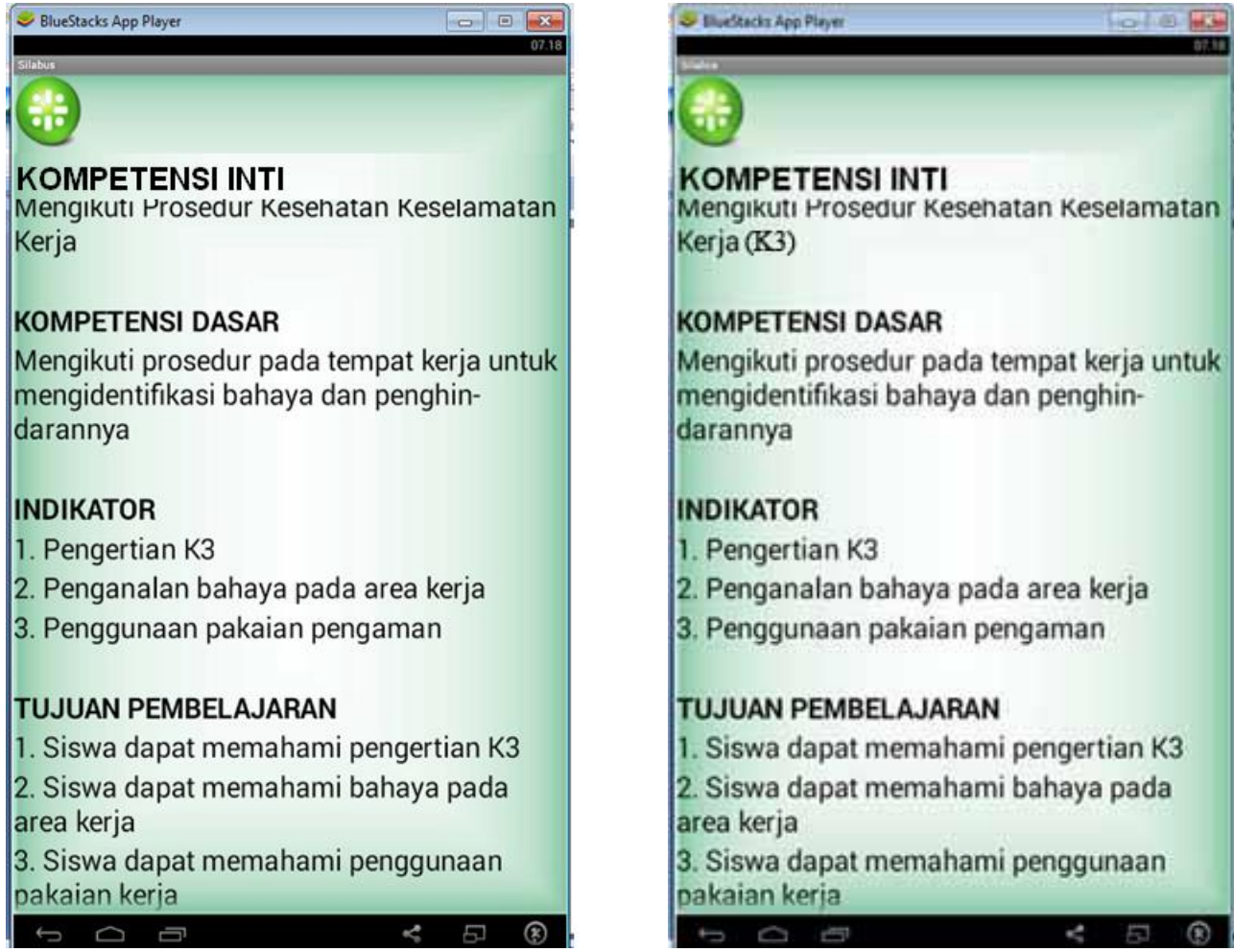

Gambar 3. Halaman silabus sebelum dan sesudah revisi
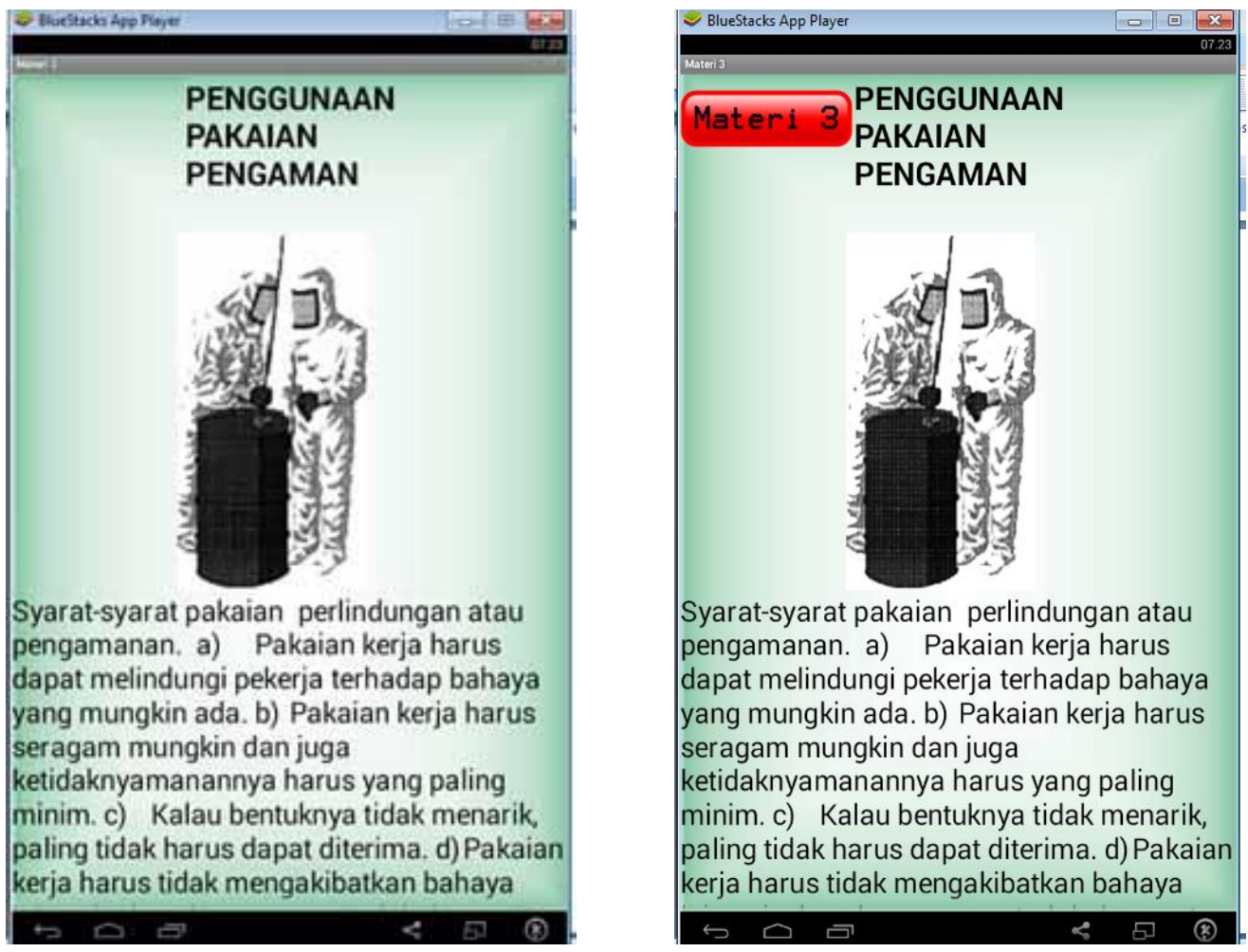

Gambar 4. Halaman materi sebelum dan sesudah revisi 

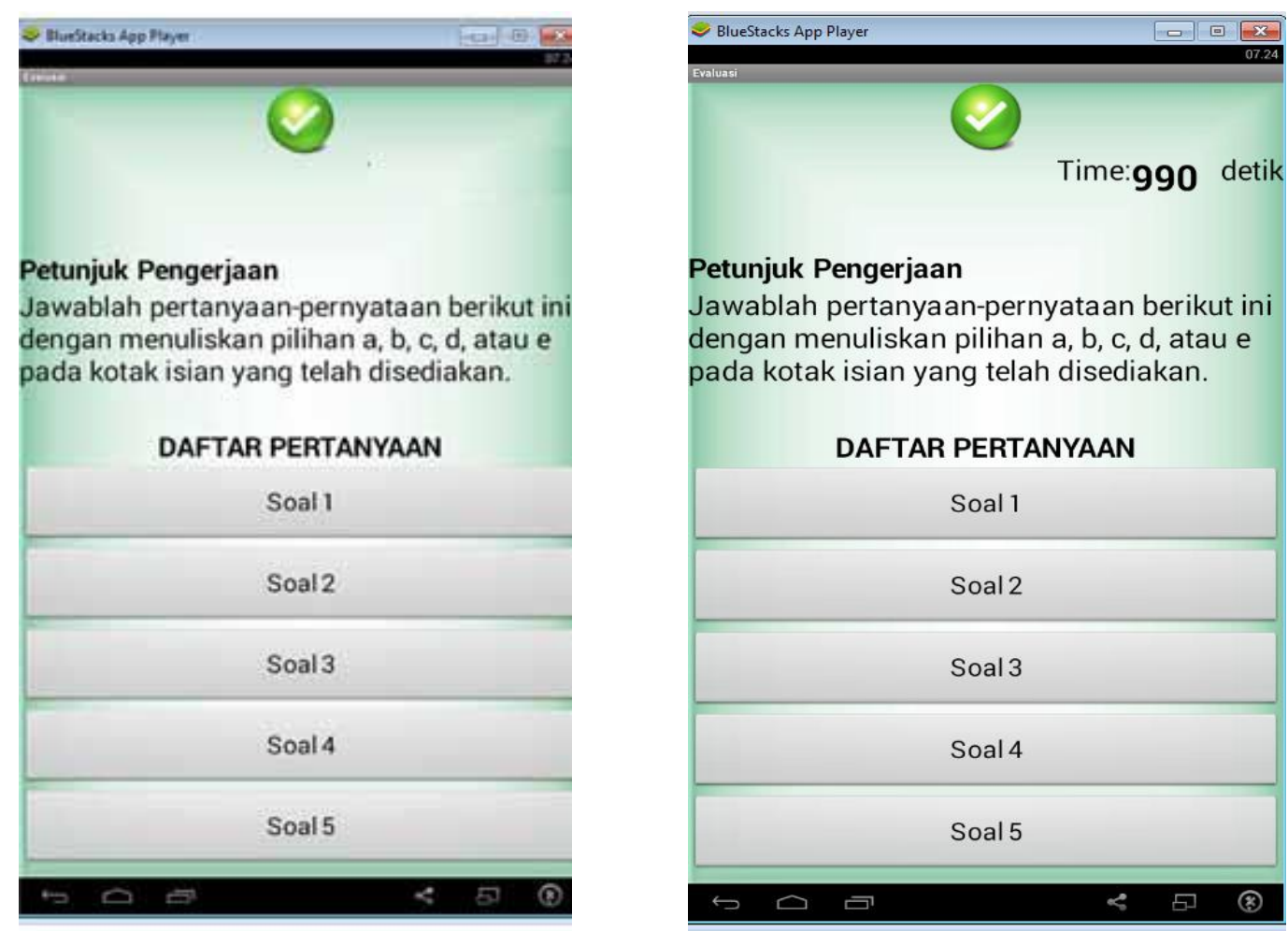

Gambar 5. Halaman soal sebelum dan sesudah revisi

Adapun perbaikan-perbaikan yang dilakukan pengembang berdasarkan komentar ahli materi di atas yang pertama adalah halaman silabus. Perubahan media ditunjukkan pada gambar 3. Selanjutnya, perbaikan yang kedua adalah penambahan label pada halaman materi. Perubahan media dapat dilihat pada gambar 4. Sedangkan perbaikan yang ketiga adalah perbaikan petunjuk waktu pengerjaan soal. Perubahan media dapat dilihat pada gambar 5.

\section{Penilaian oleh Ahli Media}

\section{Hasil Penilaian oleh Ahli Media}

Pada penilaian oleh ahli media pembelajaran ada dua aspek utama yang dinilai yaitu aspek tampilan dan penggunaan. Penilaian ini dilakukan oleh guru senior di jurusan Multimedia.. Adapun hasil penilaian oleh ahli media dapat dilihat pada gambar 6 . Berdasarkan tabel hasil penilaian media pembelajaran oleh media didapat skor rerata kelayakan dan penilaian yaitu 82\% dengan kriteria kelayakan "Sangat Layak" untuk digunakan. 


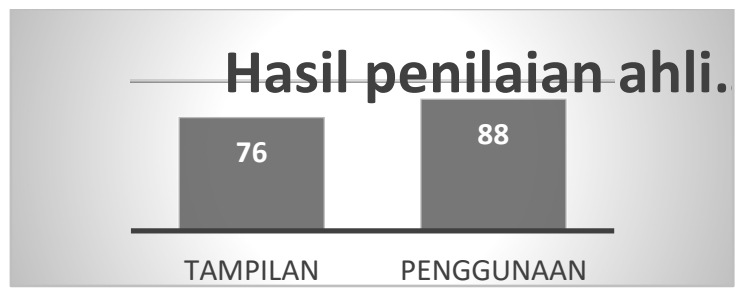

Gambar 6. Hasil Penilaian Ahli Media

2. Revisi Media Pembelajaran oleh Ahli Media

Meskipun media tersebut telah di uji coba oleh ahli media dan mendapat skor penilaian "Sangat Baik", masih ada perbaikan-perbaikan yang dilakukan. Perbaikanperbaikan tersebut sebagai bahan revisi sehingga media yang dibuat semakin baik. Adapun perbaikan-perbaikan tersebut meliputi:

a. Halaman intro diberi tombol untuk masuk halaman utama

b. Penambahan instruksi pada halaman utama.

c. menambahkan keterangan gambar pada setiap deskripsi didalam menu bantuan.

Perbaikan yang pertama penambahan tombol masuk pada menu intro. Berikut media sebelum dan setelah revisi pada gambar 7. Adapun perbaikan kedua oleh ahli media adalah masalah keterangan pada halaman utama yang perlu ditambah. Keterangan tersebut memberikan ucapan selamat datang pada pengguna aplikasi. Perbaikan ini dapat dilihat pada gambar 8. Sedangkan untuk perbaikan terakhir oleh ahli media adalah penambahan keterangan gambar tombol pada deskripsi didalam menu Bantuan/Help. Perbaikan media pada background dilihat pada gambar 9 . 

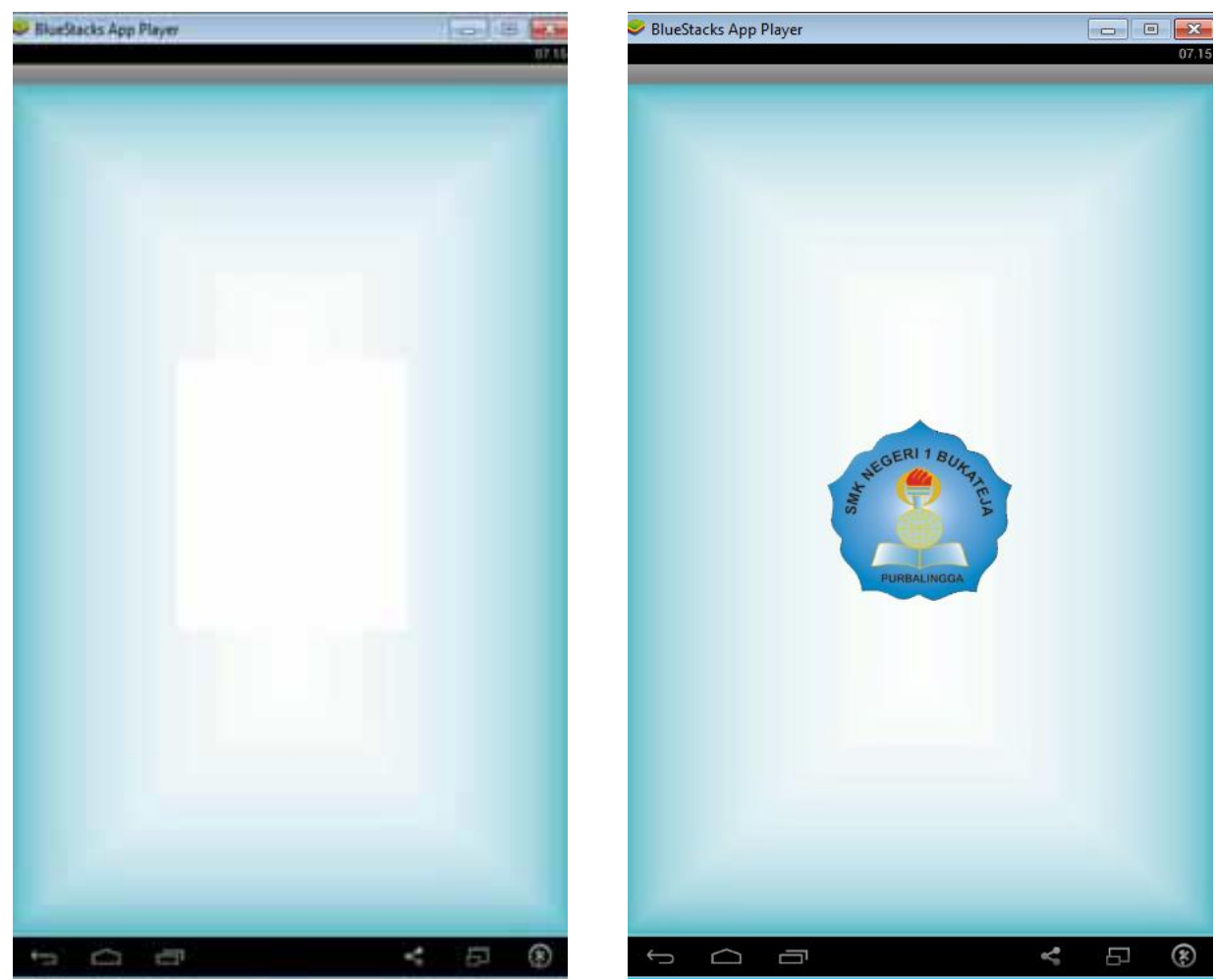

Gambar 7. Halaman intro sebelum dan sesudah revisi
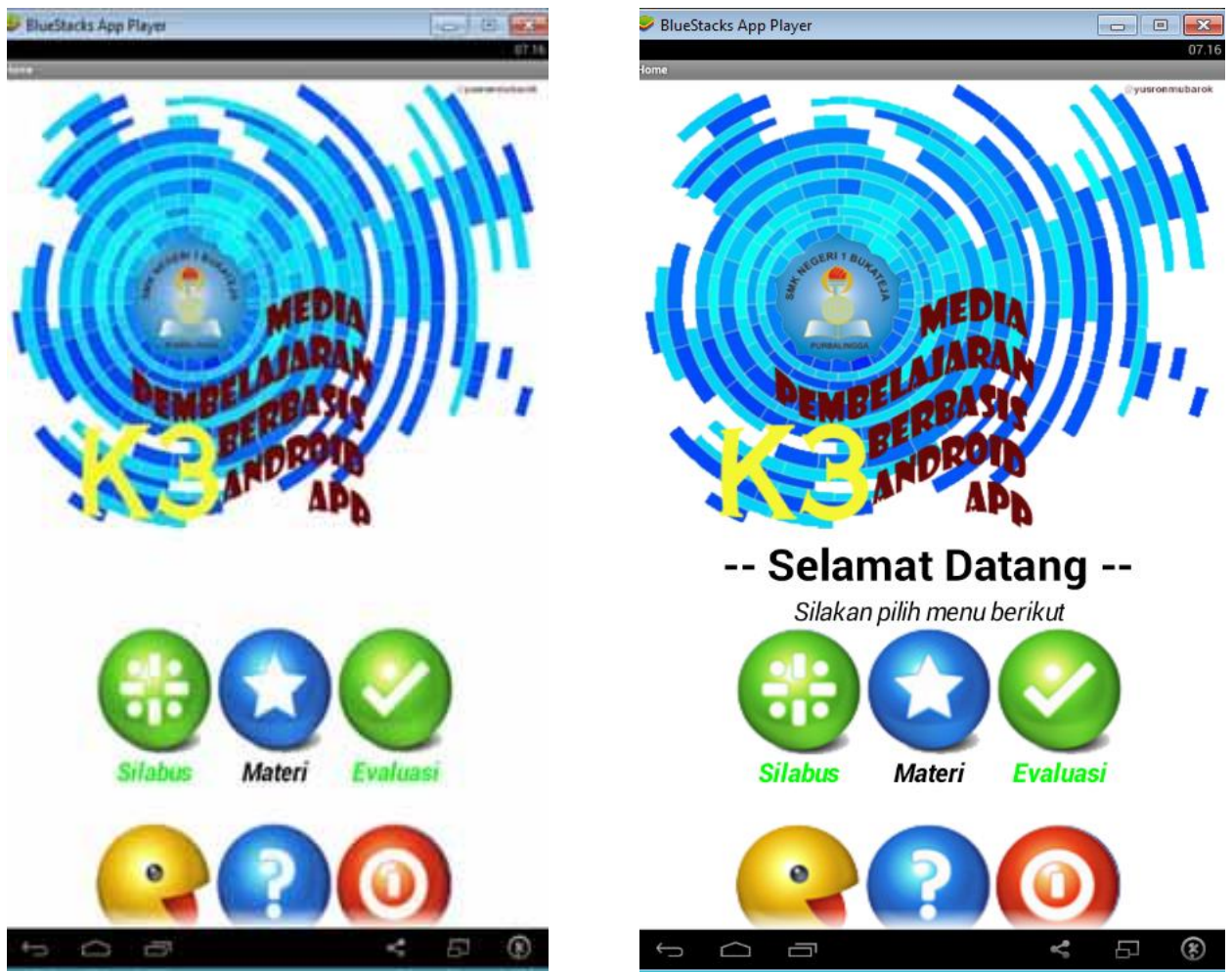

Gambar 8. Halaman utama sebelum dan sesudah revisi 

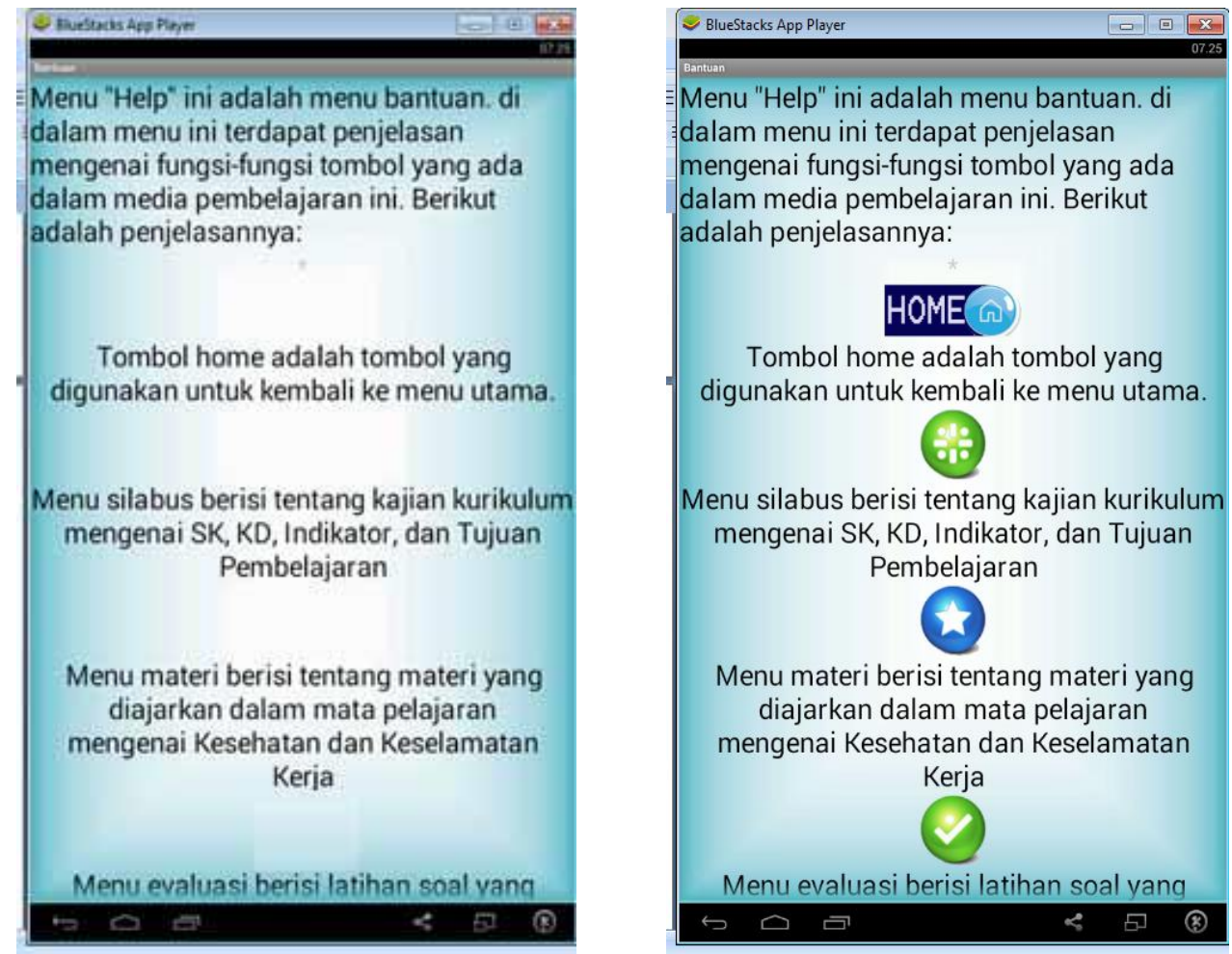

Gambar 9. Halaman bantuan sebelum dan sesudah revisi

\section{KESIMPULAN}

Berdasarkan hasil pengembangan media pembelajaran dan juga proses validasi yang sudah dilakukan maka dapat disimpulkan bahwa: (1) Identifikasi kebutuhan media ini didapatkan adalah (a) Jenis teks "Times New Roman", (b) Ukuran teks "15 pt", (c) Warna teks "Mengikuti Background", (d) Tata letak teks "Rata Kanan Kiri”, (e) Letak gambar pendukung "Pada Bagian Awal", (f) Warna background "Kebiruan", (g) Keterangan tombol "Berbentuk Teks", (h) Jenis animasi tombol "Animasi Gerak", (i) Jenis musik backsound “Off”, (j) Efek suara tombol "Klik"; (2) proses pengembangan media pembelajaran terdiri dari (a) desain produk (b) pengumpulan bahan produk, (c) pemubuatan produk, (d) validasi produk, (e) revisi produk 1, (e) Uji coba produk, (e) revisi produk 2, dan (3) kelayakan media pembelajaran secara keseluruhan dikategorikan sangat layak, sehingga media pembelajaran ini dapat digunakan.

\section{DAFTAR PUSTAKA}

Bambang. (2013). Infografis Opera: Data pengguna mobile di Indonesia (website hingga gadget terpopuler). Diakses pada tanggal 9 Januari 2019 dari 
http://gadgetan.com/infografis-opera-data-pengguna-mobile-di-indonesia-websitehingga-gadget-terpopuler/48786.

Direktur Jendral Kerjasama Perdagangan Internasional. (2014). Menuju ASEAN ECONOMICCOMMUNITY 2015. Kementerian Perdagangan Republik Indonesia.

Djoko Sumaryanto. (2005). Mengikuti Prosedur Kesehatan dan Keselamatan Kerja. Jakarta: Departeman Pendidikan Nasional.

Dwi Andi Susanto. (2013). Jumlah perangkat mobile di Indonesia ungguli jumlah penggunanya. Diakses pada tanggal 9 Januari 2019 dari http://www.merdeka.com/teknologi/jumlah-perangkat-mobile-di-indonesia-unggulijumlah-penggunanya.html.

Emzir. (2010). Metodologi Penelitian Pendidikan. Jakarta: Rajawali Press.

Endang Mulyatiningsih. (2011). Riset terapan Bidang Pendidikan dan Teknik. Yogyakarta: UNY Press

Sugiyono. (2010). Metode Penelitian Pendidikan Pendekatan Kuantitatif, Kualitatif, dan $R \& D$. Bandung: Alfabeta.

Suharsimi Arikunto, Cepi Syafrudin Abdul Jafar. (2010). Evaluasi Progam Pendidikan. Jakarta: Bumi Aksara.

Triyanto. (2010). Pengantar Penelitian Pendidikan bagi Pengembangan Profesi Pendidikan dan Tenaga Kependidikan. Jakarta: Pranandamedia. 